\title{
An Early-age Evaluation of Thermal Cracking Index of Heavy Concrete Applying for Airport Pavement
}

\author{
Trong-Chuc Nguyen ${ }^{1 *}$, Van-Lam Tang², Trong-Phuoc Huynh³ \\ 1 Institute of Techniques for Special Engineering, Le Quy Don Technical University, No. 236, Hoang Quoc Viet St., Bac Tu Liem \\ Dist., Hanoi City, Vietnam \\ 2 Faculty of Civil Engineering, Hanoi University of Mining and Geology, No. 18, Pho Vien St., Bac Tu Liem Dist., Hanoi City, Vietnam \\ ${ }^{3}$ Department of Rural Technology, College of Rural Development, Can Tho University, Campus II, 3/2 St., Ninh Kieu Dist., Can Tho \\ City 900000 , Vietnam \\ * Corresponding author, e-mail: trongchuc198@mta.edu.vn
}

Received: 14 January 2019, Accepted: 11 December 2019, Published online: 02 March 2020

\begin{abstract}
Industrial waste management has been an integral part of many countries in the world, including in Vietnam. In which, bottom ash (BA) has been used as a pozzolanic additive in compositions of the heavy concrete applying for airport concrete pavement (ACP), which allows reducing the hydration heat, the cost, and the thermal cracking of the concrete during the construction process. The purpose of this study is to summarize the experimental laboratory results of the heavy concrete samples containing $35 \%$ BA sourced from a thermal power plant in Vietnam. The mechanical and thermal properties of the heavy concrete samples were determined at different curing ages. Besides, the heat of cement hydration during the preparation of the heavy concrete in the laboratory was measured using a "TAM AIR" isothermal calorimeter. Moreover, the Midas civil computer software based on the finite element method was used to analyze the temperature field and thermal cracking index of the ACP at the early ages. As the results, the heavy concrete had the respective thermal conductivity and the average of specific heat of $1.1 \mathrm{~W} /\left(\mathrm{m} .{ }^{\circ} \mathrm{C}\right)$ and $878.35 \mathrm{~J} /\left(\mathrm{kg} .{ }^{\circ} \mathrm{C}\right)$. Moreover, the value of thermal cracking index indicates that no cracking occurred on the ACP at the early ages. Furthermore, the results of the present study can be considered as a useful reference source for future projects that are associated with the construction of the ACP.
\end{abstract}

Keywords

thermal cracking index, heavy concrete, Airport Concrete Pavement (ACP), Bottom Ash (BA), thermal analysis

\section{Introduction}

Thermal stress caused by the temperature regime in the pavement slab is vital in the structural design of the airport concrete pavement (ACP) [1]. The ACP slab is relatively thick. Therefore, the temperature in the ACP slab varies throughout the slab depth. Many factors cause cracks in the ACP at an early age. At the early age of concrete elements or structures, when the tensile strain formed from restrained thermal contraction or temperature different exceed the tensile strain capacity of concrete, cracking is the outcome. The tensile strain may also be created from early contraction caused by autogenous shrinkage [2]. $\mathrm{Xu}$ et al. [3] and Young et al. [4] reported that heat of hydration was one of the most important characteristics associated with thermal stress and concrete temperature during the early age of the pavement. Since the concrete mixture generates heat during the hydration process of cement, the pattern of concrete temperature during construction period is somewhat different from that occurred during the later ages of the concrete pavement [5].

The temperature pattern of ACP slab due to the cement hydration depends on many factors, such as the type of cement, cement content, the initial temperature of the concrete mixture, air temperature, etc. [2]. Cracking of the ACP has a relationship with the temperature change of the ACP slab. Huang et al. [6] proved that cracks occurred when the temperature difference between the center part and the surfaces of the concrete pavement was significant. Cement hydration is the process of a chemical reaction between cement and water. The amount of heat generated inside a large concrete block. Besides, the surface of the concrete block is exposed to air; they cool down faster than the interior, leading to a temperature difference in the 
concrete. The temperature difference between the center and the surface of the slab is complicated. The difference depends on space and time. It is recorded that the environment temperature changes during the day in the summer is much greater than the changing of environmental temperature during winter. Besides, the high environmental temperature during summer causes fast water evaporation, leading to a large shrinkage of concrete. As a result, the concrete pavement may have more cracks as indicated in Fig. 1. This behavior becomes more serious when the construction activities are carried out in the summer rather than in winter, especially during the first several days of the construction [7]. There are many researchers interested in concrete cracking at an early age. However, the research direction, as well as the conditions for applying research results, are still modest.

To minimize the number of cracks, therefore, the temperature rise in the ACP at an early age should be reduced. Among the methods that have been used for reducing the temperature rise in the concrete pavement, the following methods, which have particular practical application to the ACP $[8,9]$, could be considered: (i) pre-cooling concrete ingredients to reduce the fresh concrete temperature and (ii) using pozzolanic material and retarder.

Recently, the use of various industrial solid waste materials to partially replace the amount of cement in the concrete mixture not only reduces the risk of cracks in the pavement at early ages but also protects the environment, saves land area dump, saves the mineral resources for the production of construction materials, and ensures the sustainable development [10-12]. Prior published studies [13-16] reported that the use of fly ash, bottom ash (BA), and other pozzolanic materials as a cement substitution resulted in a reduction of hydration heat, thermal cracking, and production cost of concrete.

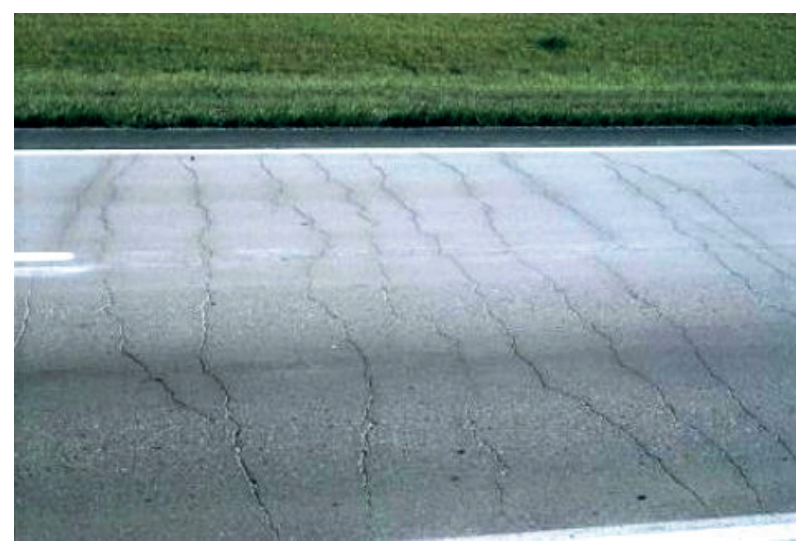

Fig. 1 Cracks that occurred in the ACP at an early age
In this paper, the preliminary proportion of the heavy concrete mixture that applied for the ACP was calculated by the ACI 211.1-2002 standard. The mechanical properties and the thermal parameters of the heavy concrete samples were determined. Additionally, the heat of hydration of the concrete was measured. Of course, there are many methods to assess the formation of cracks at the early age of concrete, and thermal cracking in the concrete depends on a lot of parameters. In which, the temperature difference and principal tensile stress are the most consideration one. Especially, when the calculated principal tensile stress exceeds the modeled tensile strength of the concrete, cracking is likely to occur. Midas civil is a famous software based on the finite element principle. It is also well-known that cracking index is one of the outputs of this software with high reliability, which is always used to evaluate the behavior of cracks at an early age of concrete.

\section{Experimental details}

\subsection{Materials}

Crushed limestone (CL) sourced from Vietnam with the particle sizes of 5-10 $\mathrm{mm}$ and $10-20 \mathrm{~mm}$ in a volume ratio of 60:40 was used as coarse aggregate in the preparation of heavy concrete samples for this investigation.

Quartz sand (QS) sourced from "Lo river" in Vietnam with fineness modulus of 3.1 was used as fine aggregate in the heavy concrete mixtures. The gradation curve of QS is displayed in Fig. 2. Also, the physical properties of both the fine and coarse aggregates are presented in Table 1.

The cement used was locally Grade 40-ordinary Portland cement (OPC) manufactured at "But Son" factory in Vietnam with the specific gravity of 3.15. The mineralogical compositions and characteristics of OPC are given in Table 2 .

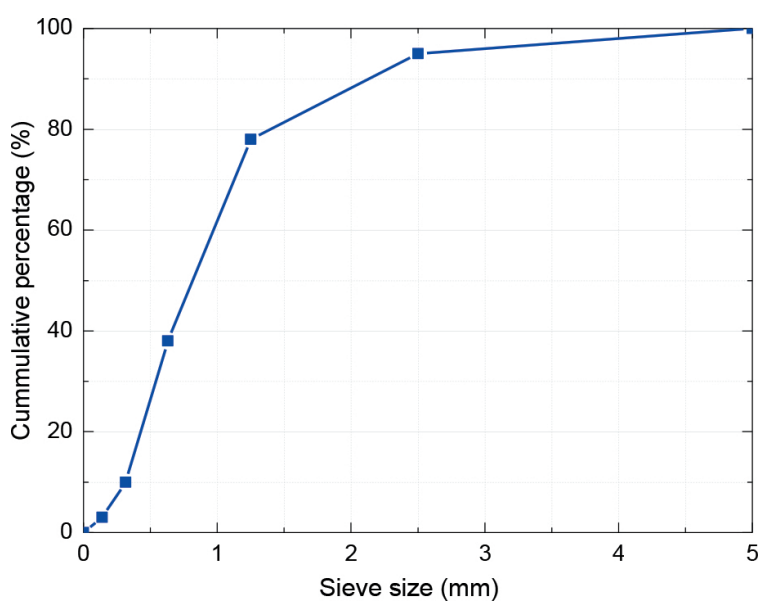

Fig. 2 Sieve analysis of fine aggregate 
Table 1 The physical properties of both fine and coarse aggregates

\begin{tabular}{lccccc}
\hline Type & $\begin{array}{c}\text { Size } \\
(\mathrm{mm})\end{array}$ & $\begin{array}{c}\text { Loose } \\
\text { density } \\
\left(\mathrm{kg} / \mathrm{m}^{3}\right)\end{array}$ & $\begin{array}{c}\text { Dry } \\
\text { density } \\
\left(\mathrm{kg} / \mathrm{m}^{3}\right)\end{array}$ & $\begin{array}{c}\text { Saturated } \\
\text { density } \\
\left(\mathrm{kg} / \mathrm{m}^{3}\right)\end{array}$ & $\begin{array}{c}\text { Water } \\
\text { absorption } \\
(\%)\end{array}$ \\
\hline CL & $10-20$ & 1445 & 2700 & 2720 & 0.45 \\
QS & $0.15-5$ & 1490 & 2650 & 2682 & 0.50 \\
\hline
\end{tabular}

Table 2 Mineralogical compositions and characteristics of OPC

\begin{tabular}{|c|c|c|c|c|c|c|c|c|c|}
\hline & 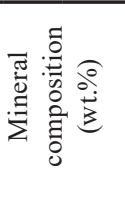 & & 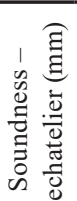 & 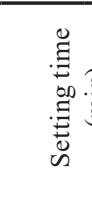 & & & 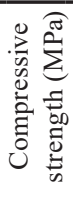 & & 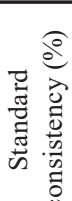 \\
\hline $\mathrm{C} 3 \mathrm{~S} \mathrm{C} 2$ & C3A C4A & & 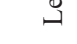 & Initial & Final & $3 d$ & $7 d$ & $28 \mathrm{~d}$ & \\
\hline 5.524 .2 & 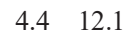 & & 1 & 150 & 230 & 30.1 & . & 51.5 & \\
\hline
\end{tabular}

Table 3 Characteristics of binder materials

\begin{tabular}{lcc}
\hline Chemical components (wt. \%) & BA & OPC \\
\hline $\mathrm{SiO}_{2}$ & 61.22 & 21.4 \\
$\mathrm{Al}_{2} \mathrm{O}_{3}$ & 21.17 & 4.5 \\
$\mathrm{Fe}_{2} \mathrm{O}_{3}$ & 5.85 & 5.1 \\
$\mathrm{SO}_{3}$ & 2.42 & 1.97 \\
$\mathrm{~K}_{2} \mathrm{O}$ & 1.25 & 1.12 \\
$\mathrm{Na}_{2} \mathrm{O}$ & 1.23 & 0.45 \\
$\mathrm{MgO}$ & 0.57 & 2.01 \\
$\mathrm{CaO}$ & 1.12 & 60.9 \\
Loss on ignition, $\mathrm{LOI}(\%)$ & 4.14 & 2.55 \\
Average particle size $(\mu \mathrm{m})$ & 6.15 & 8.37 \\
Specific gravity $\left(\mathrm{g} / \mathrm{cm}{ }^{3}\right)$ & 2.35 & 3.15 \\
Dry density $\left(\mathrm{kg} / \mathrm{m}^{3}\right)$ & 575 & 1262 \\
Surface area $\left(\mathrm{m}^{2} / \mathrm{g}\right)$ & 5.85 & 0.36 \\
\hline
\end{tabular}

The class-F bottom ash (BA) sourced from "Vung Ang", Vietnam was used as an OPC substitution. The characteristics and particle size distribution of both OPC and BA are shown in Table 3.

Local tap water (W) was used for both mixing concrete and curing of the test specimens in this study.

\subsection{Mixture proportions}

In this study, the preliminary proportion of the heavy concrete was designed following the guidelines of the ACI 211.1-2002 standard. The target properties of the heavy concrete were selected based on the requirements for the ACP application in Vietnam, including (i) The workability of the fresh concrete mixtures that measured by standard slump cone device ranges from 8 to $12 \mathrm{~cm}$; (ii) The 28-day compressive strength of the hardened concrete is greater than $30 \mathrm{MPa}$; (iii) The concrete has the water-resistant ability in the aquatic environment; (iv) The inclusion
Table 4 Mix proportions and properties of the fresh concrete

\begin{tabular}{ccccccccccc}
\hline & \multicolumn{6}{c}{ Concrete proportions $\left(\mathrm{kg} / \mathrm{m}^{3}\right)$} & $\begin{array}{c}\text { Fresh concrete properties } \\
\text { Unit weight } \\
\left(\mathrm{kg} / \mathrm{m}^{3}\right)\end{array}$ & $\begin{array}{c}\text { Slump } \\
(\mathrm{cm})\end{array}$ \\
\hline 0.45 & 0.35 & 317 & 170 & 487 & 584 & 1032 & 214 & 2311 & 11 \\
\hline${ }^{\mathrm{a}}$ W/B is water-to-binder ratio, ${ }^{\mathrm{b}} \mathrm{BA} / \mathrm{B}$ is bottom ash-to-binder ratio,
\end{tabular}
and ${ }^{\mathrm{c}} \mathrm{B}$ is binder

of about $35 \%$ BA (by mass of total binder) as an OPC replacement in the concrete mixture is required; and (v) The relative volume of entrapped air is no more than $1 \%$. The ingredient proportions for the production of the heavy concrete are shown in Table 4.

\subsection{Test methods}

Workability of the fresh concrete mixture was measured using a standard slump cone with dimensions of $100 \times 200 \times 300 \mathrm{~mm}$ as described by ASTM C143 standard and average unit weight of the fresh mixture was measured right after mixing.

The compressive strength test of the heavy concrete was performed at $1,3,7,14,28$, and 56 days using cubic samples of $150 \times 150 \times 150 \mathrm{~mm}$ as stipulated by ASTM C39 standard. The cube samples were de-molded 24 hours after casting and placed in a water curing tank at $25 \pm 2{ }^{\circ} \mathrm{C}$ until testing. The test was performed using a computer controlled compression tester with a constant loading rate of $3000 \mathrm{~N} / \mathrm{s}$ to keep the loading rate to a minimum rate in comparison with the test results of heavy concrete.

The third-points flexural strength test of the concrete was also conducted at 1, 3, 7, 14, 28, and 56 days using the $100 \times 100 \times 400 \mathrm{~mm}$ samples (ASTM C293).

The modulus of elasticity of the heavy concrete was determined through the 28-day compressive strength values of the concrete following the ACI 318-2005 standard.

The thermal conductivity $\lambda\left[\mathrm{W} /\left(\mathrm{m} .{ }^{\circ} \mathrm{C}\right)\right]$ and heat capacity $C_{v}\left[\mathrm{~J} /\left(\mathrm{kg} .{ }^{\circ} \mathrm{C}\right)\right]$ of the concrete samples were determined using heat transfer analyzer model ISOMET 2104 (Slovakia) [17-19]. The tests were conducted at a temperature of $20 \pm 5^{\circ} \mathrm{C}$ and a relative humidity of 90-95\% using concrete samples of $25 \times 25 \times 6 \mathrm{~cm}$ in size.

A "TAM AIR" isothermal calorimeter was used to analyze the exothermic hydration process of OPC and other mineral additions.

\subsection{Finite element method for thermal analysis concrete} The variation of temperature in concrete during the cement hydration is described by the Fourier equation, which depends on space and time [20-22]. 
$\frac{\partial t}{\partial \tau}=k \Delta t+\frac{q}{c \rho}$

where $k=\lambda /(c . \rho)$ is diffusivity $\left(\mathrm{m}^{2} / \mathrm{s}\right)$, $\mathrm{c}$ is specific heat $\left[\mathrm{kJ} /\left(\mathrm{kg} \cdot{ }^{\circ} \mathrm{C}\right)\right], \rho$ is density $\left(\mathrm{kg} / \mathrm{m}^{3}\right), \Delta \mathrm{t}=\operatorname{div}(\operatorname{grad} \mathrm{t})$ is Laplace temperature operator, and $q$ is thermal source $\left(\mathrm{W} / \mathrm{m}^{3}\right)$.

To determine the temperature field, it is important to know the initial and boundary conditions [23]:

The initial condition is the initial transient temperature field distribution inside the concrete. Generally, the initial instantaneous temperature field distribution is uniform. It is considered to be constant when $\tau=0, t(x, y, z, 0)=t_{o}$.

The third boundary condition is the concrete boundary air condition, which is proportional to the difference between the surface heat flow $(t)$ and the concrete surface temperature $\left(t_{s}\right)$. The boundary condition is expressed by Eq. (2):

$-\lambda \frac{\partial t}{\partial n}=h\left(t-t_{s}\right)$.

The surface in contact with the foundation is called the fourth boundary condition. The temperature and the heat flow are continuous and can be expressed by Eq. (3):

$t_{1}=t_{2} ; \frac{\lambda_{1} \partial t_{1}}{\partial n}=\frac{\lambda_{2} \partial t_{2}}{\partial n}$

where $t_{1}, \lambda_{1}$ and $t_{2}, \lambda_{2}$ are the temperature and thermal conductivity of the concrete and foundation, respectively.

To solve Eq. (1), the numerical method (finite element method) is recently used to determine the temperature field in the concrete. As aforementioned, the temperature value depends on space and time [24].

$$
t(x, y, z, \tau) » \bar{t}=\sum_{i=1}^{n} N_{i}(x, y, z) t_{i}(\tau)=[N]\{t\},
$$

where $N_{i}$ is the shape function, $n$ is the number of nodes in an element, and $t_{i}(\tau)$ is the time-dependent nodal temperatures $\tau$.

The Galerkin representation of Eq.(1) is:

$$
\begin{aligned}
& \int_{V} N_{i}\left[\frac{\partial}{\partial x}\left(k \frac{\partial t}{\partial x}\right)+\frac{\partial}{\partial y}\left(k \frac{\partial t}{\partial y}\right)+\frac{\partial}{\partial z}\left(k \frac{\partial t}{\partial z}\right)\right] d V\{t\} \\
& +\int_{S} h[N] N_{i}\{t\} d S-\int_{S} h N_{i} t_{¥} d S+\int_{S} q N_{i} d S \\
& -\int_{V} G N_{i} g V+\int_{V} \rho C[N] N_{i} d V \frac{d\{t\}}{d \tau}=0,
\end{aligned}
$$

where $h$ is the heat transfer coefficient $\left(\mathrm{W} / \mathrm{m}^{2} \cdot{ }^{\circ} \mathrm{C}\right), V$ is the volume of the element $\left(\mathrm{m}^{3}\right), S$ is the boundary conditions on the surface, $q$ is the heat flux $\left(\mathrm{W} / \mathrm{m}^{3}\right)$, and $G$ is heat generation within an element (W).

The notation is introduced as:

$$
\begin{aligned}
& {[K]=\int_{V} N_{i}\left[\frac{\partial}{\partial x}\left(k \frac{\partial t}{\partial x}\right)+\frac{\partial}{\partial y}\left(k \frac{\partial t}{\partial y}\right)+\frac{\partial}{\partial z}\left(k \frac{\partial t}{\partial z}\right)\right] d V} \\
& +\int_{S} h[N] N_{i} d S ; \\
& {[C]=\int_{V} \rho C[N] N_{i} d V ;} \\
& {[f]=\int_{S} h N_{i} t_{¥} d S-\int_{S} q N_{i} d S+\int_{V} G N_{i} g V,}
\end{aligned}
$$

where $[K]$ is the conductivity operator, $[C]$ is a capacity operator, and $[f]$ is heat load due to heat hydration.

Substitute Eq. (6) into Eq. (5), equations in matrix form can be obtained as:

$[C] \frac{d\{t\}}{d \tau}+[K]\{t\}=\{f\}$.

Considering the heat transfer with the internal source (thermal hydration of cement), the problem of heat transfer is not stable. Therefore, the time step should be divided. Applying the method of Galerkin for each element: $t(\tau)=$ $t_{i}(\tau) \mathrm{Ni}+t_{j}(\tau) N_{j} ; N_{i}=1-(\tau / \Delta \tau)$; and $N_{j}=\tau / \Delta \tau$. At each step, these equations are solved for the time and then the Eq. (7) can be written as follows:

$$
\begin{aligned}
& \left(-\frac{[C]}{2 \Delta \tau}+\frac{[K]}{3}\right)\{t\}_{(n-1) \tau}+\frac{2[K]}{3}\{t\}_{n \tau} \\
& +\left(\frac{[C]}{2 \Delta \tau}+\frac{[K]}{6}\right)\{t\}_{(n+1) \tau}=\{f\} .
\end{aligned}
$$

Thus, the temperature field in the concrete block at any time can be obtained easily by solving Eq. (8).

\subsection{The assessment of cracking in the concrete}

The assessment of cracking probability in the concrete due to the heat of hydration is considered by using Eq. (9) $[25,26]$ :

$$
I_{c t}=\frac{f_{s p}(\tau)}{f_{t}(\tau)},
$$

where $I_{c t}$ is a thermal crack index, $f_{t}(\tau)$ is the maximum thermal stress at day $\tau$, and $f_{s p}(\tau)$ is the tensile strength of concrete at day $\tau$. Both the test and evaluation of thermal 
Table 5 Thermal crack index $\left(I_{c r}\right)$

\begin{tabular}{lc}
\hline Criteria & The thermal crack index value \\
\hline To prevent cracks & $I_{c r} \geq 1.5$ \\
To limit cracks & $1.2 \leq I_{c r} \leq 1.5$ \\
To limit harmful cracks & $0.7 \leq I_{c r} \leq 1.2$ \\
\hline
\end{tabular}

crack index regarding the cracks occurred due to thermal stresses was presented. In addition, the crack criteria are listed in Table 5 [26, 27].

In recent years, there is much software based on the finite element principle to solve the problem of heat that is available in the commercial world. In this investigation, both the early-age temperature field and the stress field in the ACP were determined with the help of Midas civil software. In this study, a three-dimensional (3D) model of ACP with dimensions of $4 \times 6 \times 0.4 \mathrm{~m}$ was simulated. To improve the efficiency of the analysis, an advantage was taken of the double symmetry of the block, which allowed for the modeling of one-quarter of the block as shown in Fig. 3. The model was divided into 2688 elements and 3443 nodes [27]. It is assumed that the model was built in the North of Vietnam in June.

\section{Results and discussion}

\subsection{The properties of heavy concrete samples}

The results of slump and unit weight measurement of the fresh concrete are shown in Table 4, and the mechanical properties of the heavy concrete are given in Table 6 . As a result, the concrete samples achieved a compressive strength value of $32.45 \mathrm{MPa}$ at 28 days of curing. Whereas, the flexural strength and modulus of elasticity values were, respectively, 2.73 $\mathrm{MPa}$ and 26944.4 $\mathrm{MPa}$ at the same age.

According to ACI 318-2005 standard [28], the average modulus of elasticity $\left(E_{c}\right)$ value of concrete at 28 days can be indirectly determined by its average compressive strength $\left(R_{n} 28\right)$ following Eq. (10):

$$
E_{c}=4730 \sqrt{R_{n}^{28}}=4730 \sqrt{32.45}=26944.4(\mathrm{MPa}) .
$$

Analysis of shrinkage and creep have numerous models such as the CEB-FIP model, the ACI model, the BP model, and the exponential model. These models are also used to calculate the thermal stress of concrete. In this study, according to ACI 209.2R-08 standard [29] and the help of Midas Civil computer software, parameters that need to evaluate the creep of concrete at early age days were declared. Thus, the creep of mass concrete may be expressed by the following Eq. (11).
$J(t, \tau)=\frac{1+\varphi(t, \tau)}{E(\tau)}$,

where $J(t, \tau)$ is the creep compliance $\left(\mathrm{MPa}^{-1}\right) ; \varphi(t, \tau)$ is the coefficient of creep (equal to the ratio of creep to elastic strain).

\subsection{Determining the temperature field in the ACP}

The hydration heat evolution and the rate of the hydration heat evolution of the ACP that measured at $25^{\circ} \mathrm{C}$ are shown in Figs. 4a and 4b, respectively.

A 3D finite-element model was built with the help of Midas civil computer software to perform a coupled thermal analysis of the ACP with convection boundary conditions of concrete-air. The convection coefficient can be constant, temperature-dependent, or time-dependent. The convection coefficient was calculated using the Eq. (12):

$h=\left\{\begin{array}{l}5.6+3.9 v, v \leq 5 \mathrm{~m} / \mathrm{s} \\ 7.6 v^{0.78}, v \geq 5 \mathrm{~m} / \mathrm{s}\end{array}\right.$,

where $v$ is the wind speed $(\mathrm{m} / \mathrm{s})$.

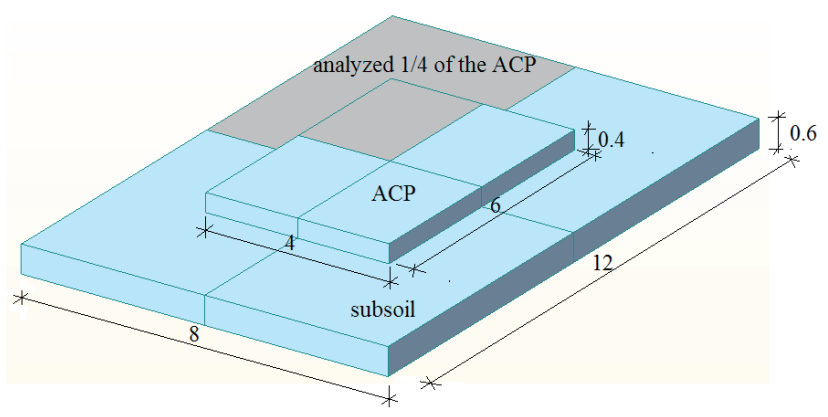

Fig. 3 Typical dimensions of an ACP studied by 3D modelFEM (unit: m)

Table 6 Mechanical properties of heavy concrete at different curing ages

\begin{tabular}{|c|c|c|c|c|c|c|c|}
\hline \multirow{2}{*}{ No. } & \multirow{2}{*}{$\begin{array}{l}\text { Properties of the } \\
\text { concrete }\end{array}$} & \multicolumn{6}{|c|}{ Curing ages (day) } \\
\hline & & 1 & 3 & 7 & 14 & 28 & 56 \\
\hline 1 & $\begin{array}{c}\text { Compressive strength } \\
(\mathrm{MPa})\end{array}$ & 5.25 & 16.17 & 25.31 & 29.48 & 32.45 & 34.82 \\
\hline 2 & $\begin{array}{l}\text { Flexural strength } \\
\qquad(\mathrm{MPa})\end{array}$ & 0.42 & 1.28 & 2.13 & 2.50 & 2.73 & 2.78 \\
\hline 3 & Dry density $\left(\mathrm{kg} / \mathrm{m}^{3}\right)$ & - & - & - & - & 2298 & - \\
\hline 4 & $\begin{array}{l}\text { Modulus of elasticity } \\
\qquad(\mathrm{MPa})\end{array}$ & - & - & - & - & 26944.4 & - \\
\hline 5 & $\begin{array}{c}\text { Thermal conductivity } \\
\lambda\left(\mathrm{W} / \mathrm{m} .{ }^{\circ} \mathrm{C}\right)\end{array}$ & - & - & - & - & 1.1 & - \\
\hline 6 & Poisson's ratio & & & & & 0.2 & \\
\hline 7 & $\begin{array}{l}\text { Specific heat } \\
{\left[\mathrm{J} /\left(\mathrm{kg} \cdot{ }^{\circ} \mathrm{C}\right)\right]}\end{array}$ & - & - & - & - & 872.35 & - \\
\hline
\end{tabular}




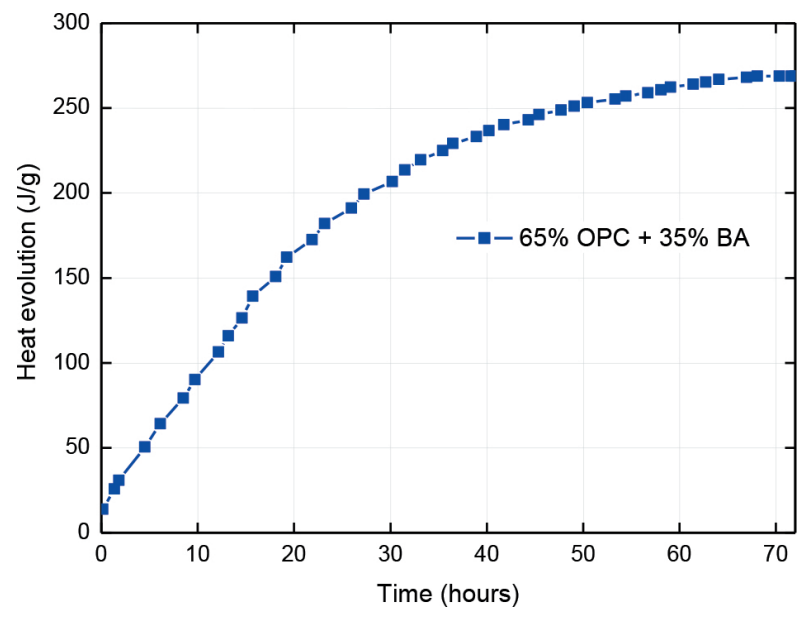

(a)

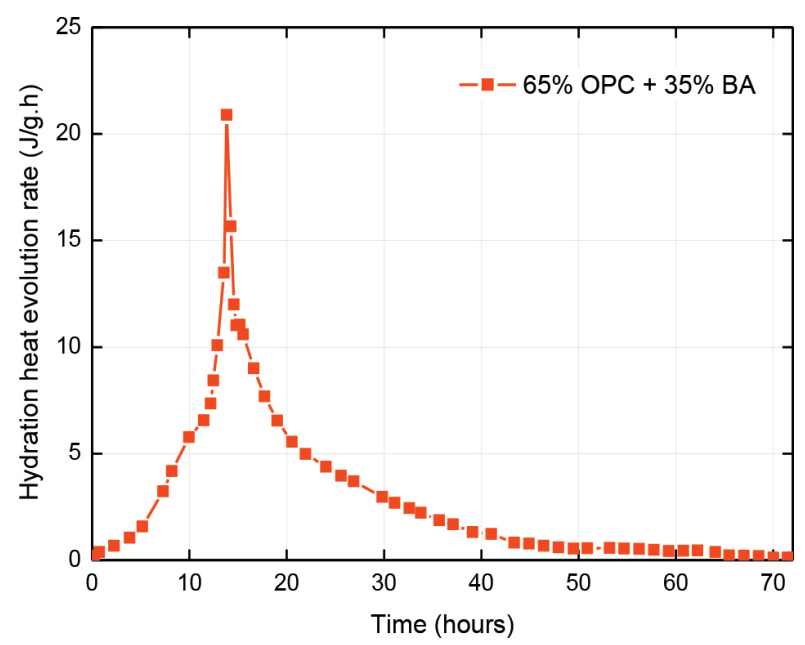

(b)

Fig. 4 Heat evolution (a) and the hydration heat evolution rate; (b) for the concrete mixture containing $65 \% \mathrm{OPC}$ and $35 \% \mathrm{BA}$

Table 7 The variation of temperature with time

\begin{tabular}{lcccccccc}
\hline Hours & 6 & 7 & 8 & 9 & 10 & 11 & 12 & 13 \\
$\left({ }^{\circ} \mathrm{C}\right)$ & 26.5 & 27.2 & 27.7 & 28.5 & 29.4 & 30.1 & 30.7 & 31.3 \\
Hours & 14 & 15 & 16 & 17 & 18 & 19 & 20 & 21 \\
$\left({ }^{\circ} \mathrm{C}\right)$ & 31.8 & 32.0 & 31.7 & 31.3 & 30.2 & 29.6 & 28.8 & 28.4 \\
Hours & 22 & 23 & 24 & 1 & 2 & 3 & 4 & 5 \\
$\left({ }^{\circ} \mathrm{C}\right)$ & 28.2 & 27.6 & 27.2 & 27.0 & 26.8 & 26.5 & 26.4 & 26.3 \\
\hline
\end{tabular}

In this research, the constant convection coefficient values of $10 \mathrm{~W} / \mathrm{m}^{2} .{ }^{\circ} \mathrm{C}$ and $7 \mathrm{~W} / \mathrm{m}^{2} .{ }^{\circ} \mathrm{C}$ were used for concrete-air $[30,31]$. The environmental temperature changed during an average day in June of the construction area in Northern Vietnam was summarized in Table 7 [32]. The initial temperature at the bottom of the slab is assigned as the temperature of subsoil (about $28.85^{\circ} \mathrm{C}$ ). The properties of the subsoil used in the analysis are presented in Table 8.

The breakdown of the calculation area into the final elements is shown in Fig. 5.
Table 8 The properties of the subsoil

\begin{tabular}{lc}
\hline Physical characteristics & Subsoil \\
\hline Thermal conduction coefficient $\left(\mathrm{W} /\left(\mathrm{m} .{ }^{\circ} \mathrm{C}\right)\right.$ & 1.96 \\
Specific heat $\left(\mathrm{kJ} / \mathrm{kg} .{ }^{\circ} \mathrm{C}\right)$ & 0.85 \\
Density $\left(\mathrm{kg} / \mathrm{m}^{3}\right)$ & 2600 \\
Convection coefficient $\left(\mathrm{W} / \mathrm{m}^{2} \cdot{ }^{\circ} \mathrm{C}\right)$ & 14.5 \\
Modulus of elasticity $\left(\mathrm{N} / \mathrm{m}^{2}\right)$ & $2.5 \times 10^{10}$ \\
Thermal expansion coefficient $\left(1 /{ }^{\circ} \mathrm{C}\right)$ & $1 \times 10^{-5}$ \\
Poisson's ratio & 0.3 \\
\hline
\end{tabular}

It is noted that the construction practice of the ACP depends on its location. Thus, the emergence of temperature cracks is usually connected with temperature differences. Temperature field at 8 nodes as marked in Fig. 5 was analyzed with the results as shown in Figs. 6 and 7. The temperature distribution of the main points at the center of the ACP was relatively stable, which primarily developed to the maximum temperature at 24 hours after laying. Node 1 located at the outside of the concrete slab, where the temperature was always lower than the inner points. The temperature at node 1 raised to the maximum temperature of $t_{\max }=35.66 \mathrm{oC}(\tau=24 \mathrm{~h})$ then decreased over time. The temperature of the nodes 2-7 increased with almost the same pattern. The temperature at node 7 was higher than that of the outside point, reaching the $t_{\max }=40.12{ }^{\circ} \mathrm{C}(\tau=24 \mathrm{~h})$ then decreasing rapidly to $t=29.93{ }^{\circ} \mathrm{C}(\tau=72 \mathrm{~h})$.

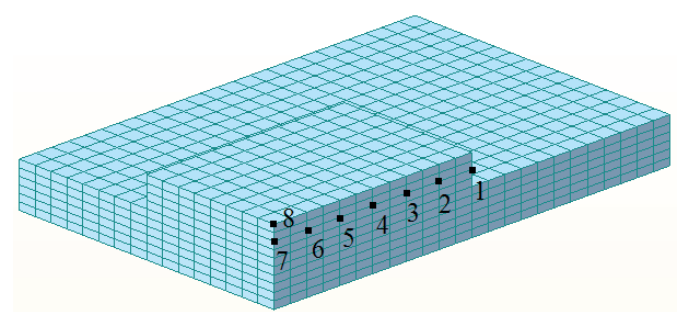

Fig. 5 Analysis of temperature field of 8 nodes in the ACP over time

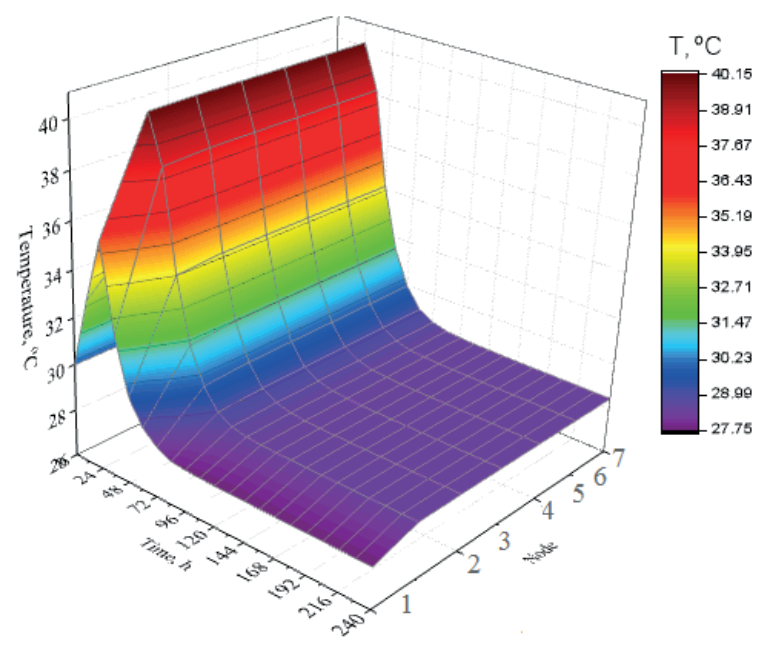

Fig. 6 Temperature field at nodes $1-7$ of the ACP over time 


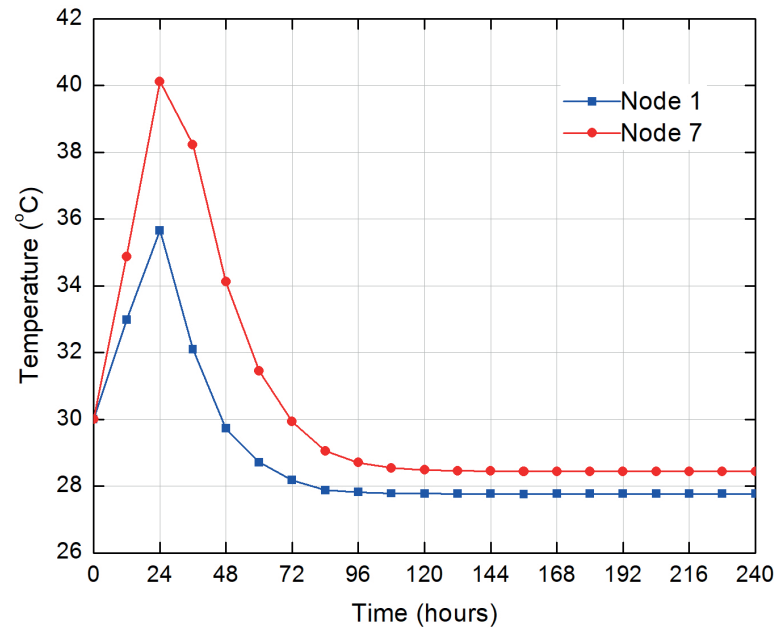

Fig. 7 Temperature field at nodes 1 and 7 of the ACP over time

When the temperature difference between the center the surface and the center - the lateral surface of the ACP exceeds the allowable limit, there are excessive stresses due to the extreme temperature gradient that appeared during the hardening process of concrete and thus resulted in the crack appearance at the surface or the lateral surface of the concrete. Therefore, analyzing the thermal cracking index and thermal stress of the two serious locations ( 1 and 8 ) was performed with the result as shown in Figs. 8 and 9. Fig. 8 shows that thermal stress change in the time of the two dangerous nodes (1 and 8) did not exceed the allowable tensile stress. Besides that, the thermal cracking index of node 8 was less than that of node 1 , which means that the risk of surface cracking at the edge of the concrete slab is higher. However, the thermal cracking index of both node 1 and node 8 was above 1.5 as previously mentioned in Table 5 , indicating that no cracking occurred on the ACP at the early ages.

\section{Conclusions}

The prediction of the temperature regime and the evaluation of crack risk of the heavy concrete applying for airport pavement were proposed in the present study. The following conclusions can be drawn:

1. The preliminary composition of the heavy concrete mixture with a slump value of $11 \mathrm{~cm}$ was calculated following the instructions of ACI 211.1-2002 standard, and the concrete registered the 28-day compressive strength and flexural strength values of $32.45 \mathrm{MPa}$ and $2.73 \mathrm{MPa}$, respectively.

2. The experimental thermal analysis shows that the heavy concrete had the respective thermal conductivity and the average of specific heat of $1.1 \mathrm{~W} /\left(\mathrm{m} .{ }^{\circ} \mathrm{C}\right)$ and $878.35 \mathrm{~J} /\left(\mathrm{kg} .{ }^{\circ} \mathrm{C}\right)$.

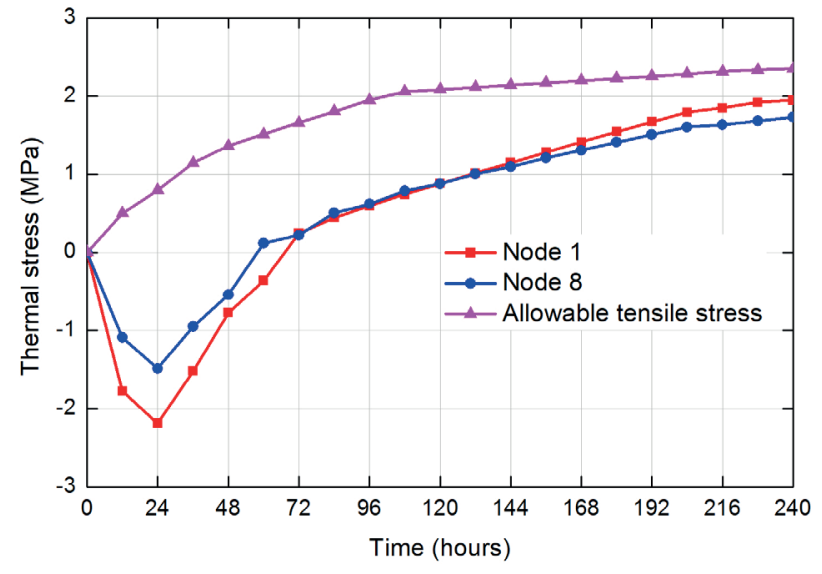

Fig. 8 The thermal cracking index at nodes 1 and 8 of the ACP over time

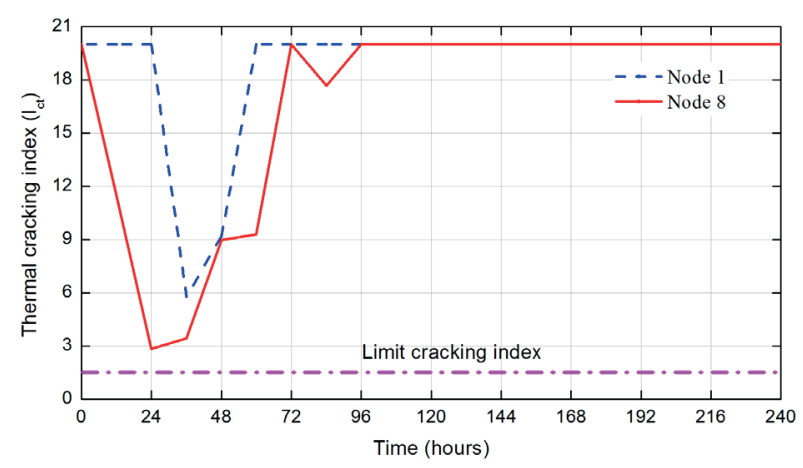

Fig. 9 The thermal cracking index at nodes 1 and 8 of the ACP over time

3. The hydration heat evolution and the rate of the hydration heat evolution of the heavy concrete samples were accurately determined using a "TAM AIR" isothermal calorimeter.

4. Temperature difference at the center (node 7) - the the lateral surface (node 1) and at the center (node 7) - the outer surfaces (node 8) of ACP reached respectively $5.35^{\circ} \mathrm{C}$ and $4.43^{\circ} \mathrm{C}$ after 24 hours, and the value decreased at further observation time. On the other hand, the thermal cracking index both at the surface and at the center of the ACP slab was greater than 1.5. This indicates that no cracking occurred on the ACP at early ages.

5. The model of finite element mesh is developed for simulation analysis of temperature and thermal stress distribution for airport pavement as well as evaluating the cracking index at an early age. Based on the numerical model results, the engineers can predict the thermal distribution, thermal stress and cracking index formed with different construction conditions in order to control cracking and chosen factors appropriately. 


\section{References}

[1] Nishizawa, T., Ozeki, T., Katoh, K., Matsui, K. "Finite Element Model Analysis of Thermal Stresses of Thick Airport Concrete Pavement Slabs", Transportation Research Record: Journal of the Transportation Research Board, 2095(1), pp. 3-12, 2009.

https://doi.org/10.3141/2095-01

[2] Safiuddin, Md., Amrul Kaish, A. B. M., Woon, C.-O., Raman, S. N. "Early-Age Cracking in Concrete: Causes, Consequences, Remedial Measures, and Recommendations", Applied Sciences, 8(10), Article number: 1730, 2018.

https://doi.org/10.3390/app8101730

[3] Xu, Q., Ruiz, J. M., Hu, J., Wang, K., Rasmussen, R. O. "Modeling hydration properties and temperature developments of early-age concrete pavement using calorimetry tests", Thermochimica Acta, 512(1-2), pp. 76-85, 2011. https://doi.org/10.1016/j.tca.2010.09.003

[4] Young, B. A., Falzone, G., She, Z., Thiele, A. M., Wei, Z., Neithalath, N., Sant, G., Pilon, L. "Early-age temperature evolutions in concrete pavements containing micro-encapsulated phase change materials", Construction and Building Materials, 147, pp. 466-477, 2017. https://doi.org/10.1016/j.conbuildmat.2017.04.150

[5] Arora, A., Sant, G., Neithalath, N. "Numerical simulations to quantify the influence of phase change materials (PCMs) on the earlyand later-age thermal response of concrete pavements", Cement and Concrete Composites, 81, pp. 11-24, 2017. https://doi.org/10.1016/j.cemconcomp.2017.04.006

[6] Huang, Y., Liu, G., Huang, S., Rao, R., Hu, C. "Experimental and finite element investigations on the temperature field of a massive bridge pier caused by the hydration heat of concrete", Construction and Building Materials, 192, pp. 240-252, 2018.

https://doi.org/10.1016/j.conbuildmat.2018.10.128

[7] Suh, Y.-C., Hankins, K., McCullough, B. F. "Early-age behavior of continuously reinforced concrete pavement and calibration of the failure prediction model in the CRCP-7 program", The University of Texas at Austin, Austin, TX, USA, Rep. 1244-3, 1992. [online] Available at: https://ibrary.ctr.utexas.edu/digitized/texasarchive/ phase2/1244-3.pdf [Accessed: 20 December 2019]

[8] Singh, P. R., Rai, D. C. "Effect of Piped Water Cooling on Thermal Stress in Mass Concrete at Early Ages", Journal of Engineering Mechanics, 144(3), 2018.

https://doi.org/10.1061/(ASCE)EM.1943-7889.0001418

[9] Modarres, A., Hosseini, Z. "Mechanical properties of roller compacted concrete containing rice husk ash with original and recycled asphalt pavement material", Materials \& Design, 64, pp. 227-236, 2014.

https://doi.org/10.1016/j.matdes.2014.07.072

[10] Atiş, C. D. "Heat evolution of high-volume fly ash concrete", Cement and Concrete Research, 32(5), pp. 751-756, 2002. https://doi.org/10.1016/S0008-8846(01)00755-4

[11] Lam, T. V, Nguyen, T. C., Hung, N. X., Phi, D. V., Bulgakov, B., Bazhenova, S. "Effect of natural pozzolan on strength and temperature distribution of heavyweight concrete at early ages", MATEC Web of Conferences, 193, Article number: 03024, 2018. https://doi.org/10.1051/matecconf/201819303024
[12] Tang, L. V., Bulgakov, B., Bazhenova, S., Aleksandrova, O., Pham, A. N., Vu, T. D. "Effect of Rice Husk Ash and Fly Ash on the Workability of Concrete Mixture in the High-Rise Construction", E3S Web of Conferences, 33, Article number: 02029, 2018. https://doi.org/10.1051/e3sconf/20183302029

[13] Lam, T. V., Bulgakov, B., Aleksandrova, O., Larsen, O., Anh, P. N. "Effect of rice husk ash and fly ash on the compressive strength of high performance concrete", E3S Web of Conferences, 33, Article number: 02030, 2018. https://doi.org/10.1051/e3sconf/20183302030

[14] Šavija, B., Schlangen, E. "Use of phase change materials (PCMs) to mitigate early age thermal cracking in concrete: Theoretical considerations", Construction and Building Materials, 126, pp. 332-344, 2016

https://doi.org/10.1016/j.conbuildmat.2016.09.046

[15] Lee, K.-C., Cho, J.-W., Jung, S.-H., Jay Kim, J.-H. "Study on Hydration Heat of Blended Belite Binder", Journal of the Korea Concrete Institute, 23(2), pp. 145-150, 2011 https://doi.org/10.4334/JKCI.2011.23.2.145

[16] Nguyen, T. C., Lam, V. T., Bulgakov, B. I. "Designing the composition of concrete with mineral additives and assessment of the possibility of cracking in cement-concrete pavement", Materials Science Forum, 931, pp. 667-673, 2018.

https://doi.org/10.4028/www.scientific.net/MSF.931.667

[17] Siwińska, A., Garbalińska, H. "Thermal conductivity coefficient of cement-based mortars as air relative humidity function", Heat and Mass Transfer, 47, pp. 1077-1087, 2011. https://doi.org/10.1007/s00231-011-0772-1

[18] Pichór, W. "Properties of autoclaved aerated concretes with cenospheres from coal ash", Cement, Wapno, Beton, 1(1), pp. 32-37, 2012 .

[19] Glinicki, M.A., Jaskulski, R., Pichór, W., Dąbrowski, M., Sobczak, M. "Investigation of Thermal Properties of Shielding Concrete", presented at 11th International Symposium on Brittle Matrix Composites, Warsaw, Poland, Sept, 28-30, 2015 https://doi.org/10.13140/RG.2.1.1045.0403

[20] Fairbairn, E. M. R., Silvoso, M. M., Ribeiro, F. L. B., Toledo-Filho, R. D. "Determining the adiabatic temperature rise of concrete by inverse analysis: case study of a spillway gate pier", European Journal of Environmental and Civil Engineering, 21(3), pp. 272288, 2017. https://doi.org/10.1080/19648189.2015.1112843

[21] Xu, Y., Xu, Q., Chen, S., Li, X. "Self-restraint thermal stress in early-age concrete samples and its evaluation", Construction and Building Materials, 134, pp. 104-115, 2017. https://doi.org/10.1016/j.conbuildmat.2016.12.066

[22] Zhou, W., Li, L., Liu, S., Dao Vinh, T. N., Liu, X. "Hydration properties and thermal analysis of cement-based materials containing limestone powder", Journal of Central South University, 24, pp. 2932-2939, 2017 https://doi.org/10.1007/s11771-017-3707-2

[23] Shi, N., Zhang, R., Huang, D. "Thermal stress analyses and reinforcement design of massive RC structures", European Journal of Environmental and Civil Engineering, 19(8), pp. 901-916, 2015. https://doi.org/10.1080/19648189.2014.985849 
[24] Qin, H., Zhang, Q., Wan, S. "The continuous Galerkin finite element methods for linear neutral delay differential equations", Applied Mathematics and Computation, 346, pp. 76-85, 2018. https://doi.org/10.1016/j.amc.2018.10.056

[25] Bobko, C. P., Edwards, A. J., Seracino, R., Zia, P. "Thermal Cracking of Mass Concrete Bridge Footings in Coastal Environments", Journal of Performance of Constructed Facilities, 29(6), 2015. https://doi.org/10.1061/(ASCE)CF.1943-5509.0000664

[26] Lee, M. H., Chae, Y. S., Khil, B. S., Yun, H. D. "Influence of casting temperature on the heat of hydration in mass concrete foundation with ternary cements", Applied Mechanics and Materials, 525, pp. 478-481, 2014.

https://doi.org/10.4028/www.scientific.net/AMM.525.478

[27] Klemczak, B., Batog, M., Pilch, M., Żmij, A. "Analysis of Cracking Risk in Early Age Mass Concrete with Different Aggregate Types", Procedia Engineering, 193, pp. 234-241, 2017. https://doi.org/10.1016/j.proeng.2017.06.209

[28] ACI "ACI 318-05 Building code requirements for structural concrete", American Concrete Institute, Farmington Hills, MI, USA, 2005
[29] ACI "209.2R-08 Guide for Modeling and Calculating Shrinkage and Creep in Hardened Concrete", American Concrete Institute, Farmington Hills, MI, USA, 2008.

[30] Kuriakose, B., Nageswara Rao, B., Dodagoudar, G. R. "Earlyage Temperature Distribution in a Massive Concrete Foundation", Procedia Technology, 25, pp. 107-114, 2016. https://doi.org/10.1016/j.protcy.2016.08.087

[31] Do, T. A., Lawrence, A. M., Tia, M., Bergin, M. J. "Importance of Insulation at the Bottom of Mass Concrete Placed on Soil with High Groundwater", Transportation Research Record: Journal of the Transportation Research Board, 2342(1), pp. 113-120, 2013. https://doi.org/10.3141/2342-14

[32] Aniskin, N., Nguyen, T. C., Hoang, Q. L. "Influence of size and construction schedule of massive concrete structures on its temperature regime", MATEC Web of Conferences, 251, Article number: 02014, 2018.

https://doi.org/10.1051/matecconf/201825102014 